\title{
MICROMORPHOLOGICAL ASSESSMENT OF LEAVES OF AMARANTHUS CAUDATUS L. CULTIVATED ON FORMULATED SOIL TYPES
}

\author{
JiMOH, M. O. ${ }^{1}-$ AFOLAYAN, A. J. ${ }^{1 *}-$ LEWU, F. B. ${ }^{2}$ \\ ${ }^{I}$ Medicinal Plants and Economic Development (MPED) Research Centre, Department of \\ Botany, University of Fort Hare, Alice 5700, South Africa \\ (e-mail:moajay006@gmail.com) \\ ${ }^{2}$ Department of Agriculture, Cape Peninsula University of Technology, Wellington Campus, \\ Wellington 7654, Cape Town, South Africa \\ (e-mail:LewuF@cput.ac.za) \\ *Corresponding author \\ e-mail: aafolayan@ufh.ac.za; phone: +27-82-202-2167
}

(Received $6^{\text {th }}$ Apr 2019; accepted $13^{\text {th }}$ Jun 2019)

\begin{abstract}
This study examined the modification of foliar characters in the leaf of Amaranthus caudatus cultivated on formulated soils. The soil types namely; sandy clay loam, silty clay loam, clayey loam and loam were experimentally derived from sieved soil particles of sand, silt and clay that were re-mixed in relative proportions proposed by the United States Department of Agriculture (USDA, 1951) while unfractionated soil served as the control. The Energy Dispersive X-Ray Spectroscopy (SEM-EDX) showed variation in percentage elemental composition of the epidermal layers. Harvests from clayey loam soil (with relative equal compositions of sand, silt and clay) had the highest composition of the following elements; nitrogen, oxygen, sodium, phosphorus, calcium and zinc whereas other elements were present in various proportions on epidermal surfaces of harvests from other soils. The Scanning Electron Microscope revealed non-glandular dish-like peltate trichomes with membranous lids attached in some cases. On the abaxial layer, stomata densities of the harvests from various soils were in this order: clayey loam > loam > sandy clay loam > control soil > silty clay loam. This research, therefore, provided supportive data on the effect of formulated soil on stomatal development and distribution in Amaranthus caudatus.
\end{abstract}

Keywords: Amaranthus caudatus, foliar characters, spectroscopy, stomata, dish-like peltate trichomes

\section{Introduction}

Grain amaranths were important crops to the people of Mayan, Aztec and Incas of the pre-Columbian era. They belong to the family Amaranthaceae (now including former family Chenopodiaceae), comprising of grain crops, vegetables, ornamental herbs, shrubs and dye plants numbering about 2500 species globally (The Angiosperm Phylogeny Group, 2009; Christenhusz and Byng, 2016; Kadereit et al., 2003). The existence of wide taxonomic and morphology characters between and within Amaranthus species (Juan et al., 2007) makes it important to study possible cause due to environmental factors. Amaranthus caudatus is one of the few ancient dicotyledonous pseudo cereals of Amaranthaceae. Its origin has been traced to the Andean countries and it is well known to survive in marginal climates where other crops cannot be easily cultivated (Jimoh et al., 2018).

The technique of micromorphology has proven to be more reliable in provision of data for germplasm identification and in unravelling structures of taxonomic importance that are embedded in plant cell or tissue for adequate knowledge of genetic diversity 
(Costea et al., 2006; Shah et al., 2018). Also, for the enhancement of cultivars for better yield, it is important to understand the magnitude of environmental influence on these factors (Rastogi and Shukla, 2013).

Many environmental conditions such as moisture, light, temperature and a host of other geographic factors have been reported to affect genetic make-up of species naturally or artificially. The soil environment plays a key role in plant gene expression (Viger et al., 2015). Also, it has been well established that soil texture determines the moisture retention capacity and water infiltration rate which in turn influences the amount of nutrients available to plant although for different soil structures, the two factors are inversely related (Olesen et al., 1999; Rabot et al., 2018). The photosynthetic biochemistry of plant coupled with soil factor and other environmental conditions drive the mechanism for stomatal acclimation to atmospheric carbon IV oxide (Maherali et al., 2002; Pillitteri and Torii, 2012). Since environmental condition is capable of altering the entire plant structures such as leaf size, stem girth and root length; its overall effect on stomatal size, density, distribution and conductivity cannot be underestimated (Casson and Gray, 2008; Maherali et al., 2002; Jimoh et al., 2019a).

Apart from being a depot for bioactive compounds, plant leaf houses important organs responsible for physiological functions and stomata, useful in taxonomic characterization. For example, epidermal features have been recently recognized as supportive tool for systematic delimitation within and between species implying that foliar micromorphology is a true reflection of interaction between plant and its environment (Fank-De-Carvalho et al., 2010; Sharaibi and Afolayan, 2017; Stuessy, 2009). The core objective of this research therefore, was to investigate induced morphological adjustments to foliar characteristics of Amaranthus caudatus cultivated plants on different soil types and incorporate newly acquired information into existing taxonomic database for the species.

\section{Materials and methods}

\section{Experimental soil formulation}

Top soil collected from the University of Fort Hare's Research Farm in May 2017 was air dried under shade for 4 weeks. The dried soil was later filtered with iron sieves of the designated mesh into parent particle sizes of clay $(<2 \mu \mathrm{m})$, silt $(<50-2 \mu \mathrm{m})$ and sand $(<2000-50 \mu \mathrm{m})$. Experimental soil was then formulated by mixing sieved soil particles in relative proportions proposed by the United States Department of Agriculture (United States Department of Agriculture \& Natural Resources Conservation Service, 1983) soil texture triangle as shown in Table 1.

Table 1. Experimental soil formulation in proportions recommended by soil texture triangle technique (USDA, 1951)

\begin{tabular}{c|c|c|c|c}
\hline S/N & Soil types & \% Sand & \% Silt & \% Clay \\
\hline 1 & Control soil $\left(\mathrm{SF}_{1}\right)$ & Unfractionated & Unfractionated & Unfractionated \\
2 & Sandy clay loam $\left(\mathrm{SF}_{2}\right)$ & 66 & 13 & 21 \\
3 & Silty clay loam $\left(\mathrm{SF}_{3}\right)$ & 10 & 60 & 30 \\
4 & Clayey loam $\left(\mathrm{SF}_{4}\right)$ & 36 & 30 & 34 \\
5 & Loam $\left(\mathrm{SF}_{5}\right)$ & 40 & 40 & 20 \\
\hline
\end{tabular}




\section{Plant material and experimental design}

Seeds of A. caudatus collected from seedbank of the Medicinal Plants and Economic Development (MPED) Research Centre, Department of Botany, University of Fort Hare were broadcast in seedling trays and transplanted after three weeks into pots filled with the control and formulated soils types (Table 1) arranged in the green house in a Completely Randomised Design (CRD) in three replicates (Fig. 1). The experiment was conducted in the greenhouse (set at an average temperature of $25{ }^{\circ} \mathrm{C} ; 64 \%$ relative humidity), sited on the roof of the Department of Botany building. At flowering stage, fresh and mature leaves were collected at five nodes to the shoot apices, from three different pots representing each of the soil types. Portions of 2-3 $\mathrm{cm}^{2}$ were cut off from the standard median part of the leaf blade close to the mid-rib in preparation for micromorphological examination.

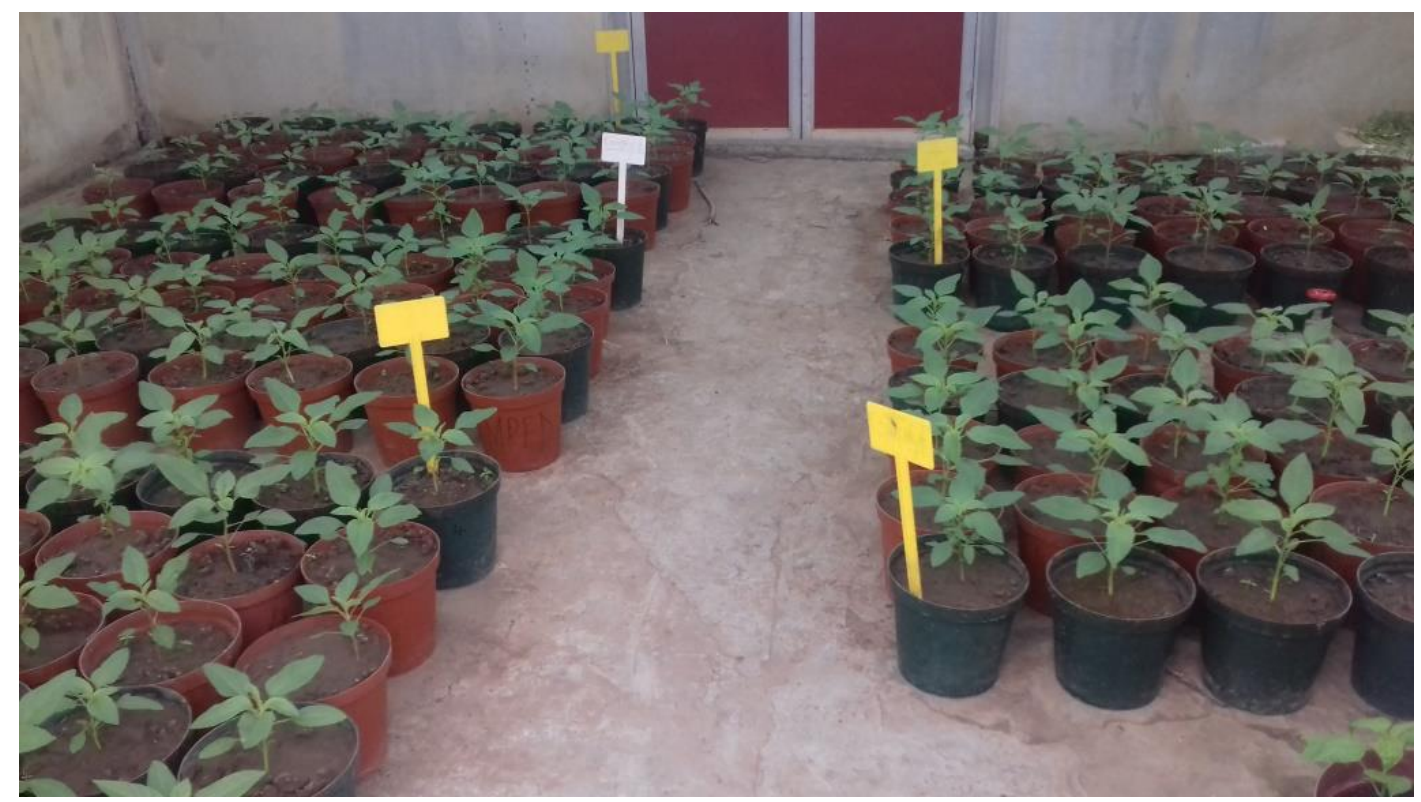

Figure 1. Potted experiment of Amaranthus caudatus in a green house

\section{Scanning electron microscopy and energy dispersive X-ray spectroscopy (SEM-EDX)}

Cut sections of the leaf were fixed in $6 \%$ glutaraldehyde solution buffered with $0.05 \mathrm{M}$ sodium cacodylate $(\mathrm{pH} 7.5)$ for $24 \mathrm{~h}$. The samples were soaked in distilled water and dehydrated in graded ethanol (10-100\% concentration series) for 20 min per rinse (Munien et al., 2015). Samples were then soaked in 100\% ethanol and dried in a Hitachi HCP-2 critical point drier. Dried specimens were fixed with two sided adhesive carbon tape on aluminium stubs and coated with a thin layer of gold using an Elko IB-3 Ion Coater. The abaxial and adaxial surfaces were examined in a JEOL (JSM-6390LV) Scanning Electron Microscope (SEM) operating at an accelerated voltage of 10-15 kV at different magnifications. The Energy Dispersive X-Ray Spectroscopy (produced by Thermo Electron Corporation, 6733B-IUUSN, USA) and the Noran System Six Imaging Software both connected to SEM were respectively used to analyse the elemental composition of the treated samples and capture electron images (Sharaibi and Afolayan, 2017). Both qualitative and quantitative features on the abaxial and adaxial layers of the leaf epidermis were assessed. Quantitative features examined were number 
of trichomes; stomata density and distance between two stomata. The qualitative characters considered were stomata distribution; trichome types, size, shape and distribution; presence or absence of peltate scale; and oil sac frequency on both layers.

\section{Statistical analysis}

Data obtained from all treatments were analysed and expressed as mean \pm standard deviation (SD) of 3 replicates. A MINITAB 17 statistical package was used to separate means of various replicate data for EDX percentage elemental compositions, stomata densities and distances between stomata.

\section{Results}

\section{Foliar micromorphological characters}

\section{Stomata}

Stomata types and distribution: Leaves are amphistomatic with both layers characterized by sunken, anomocytic stomata lacking subsidiary cells. Stomata were found to be prevalent on the abaxial surface than the adaxial in all soil types (Fig. 2).
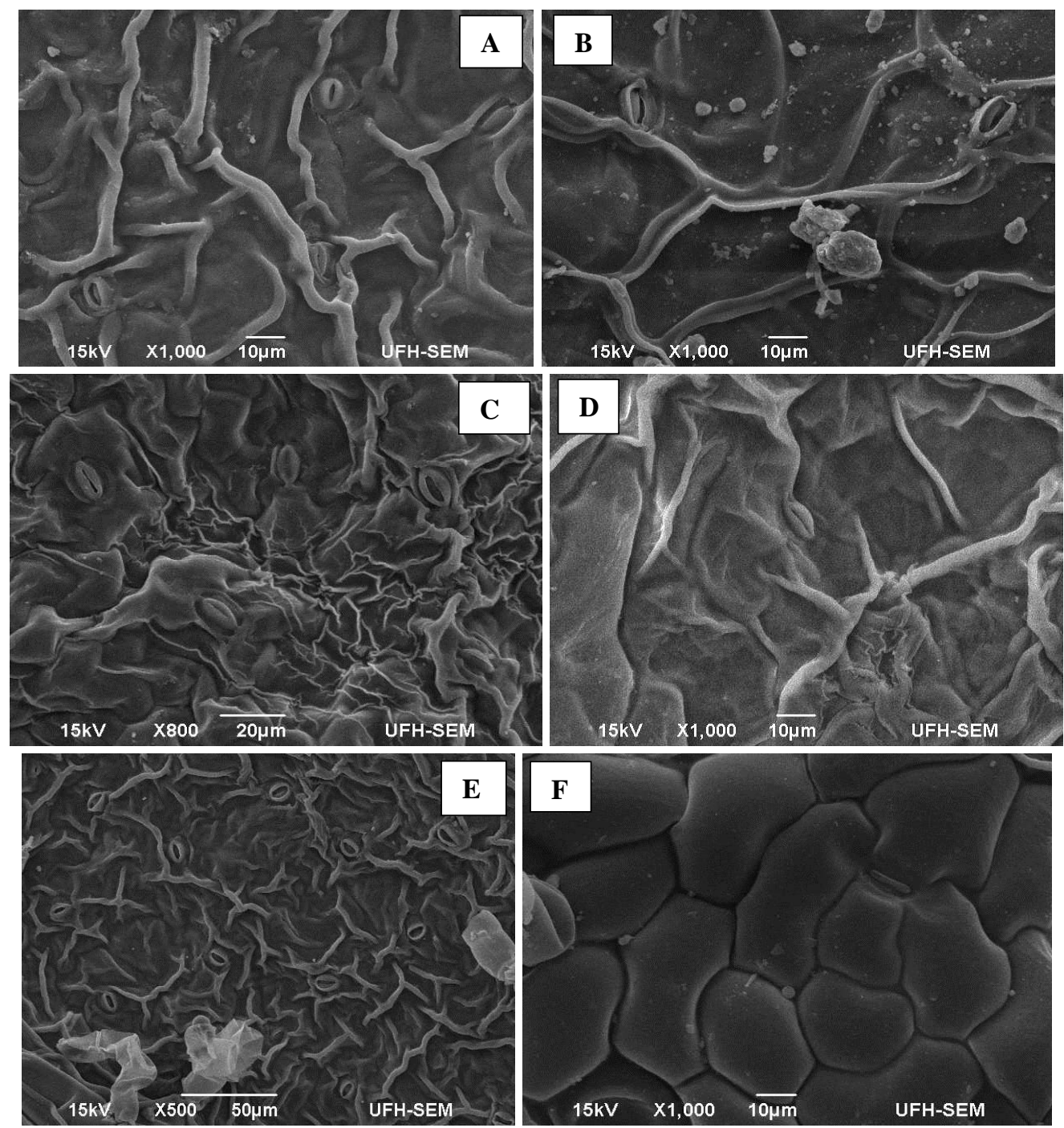

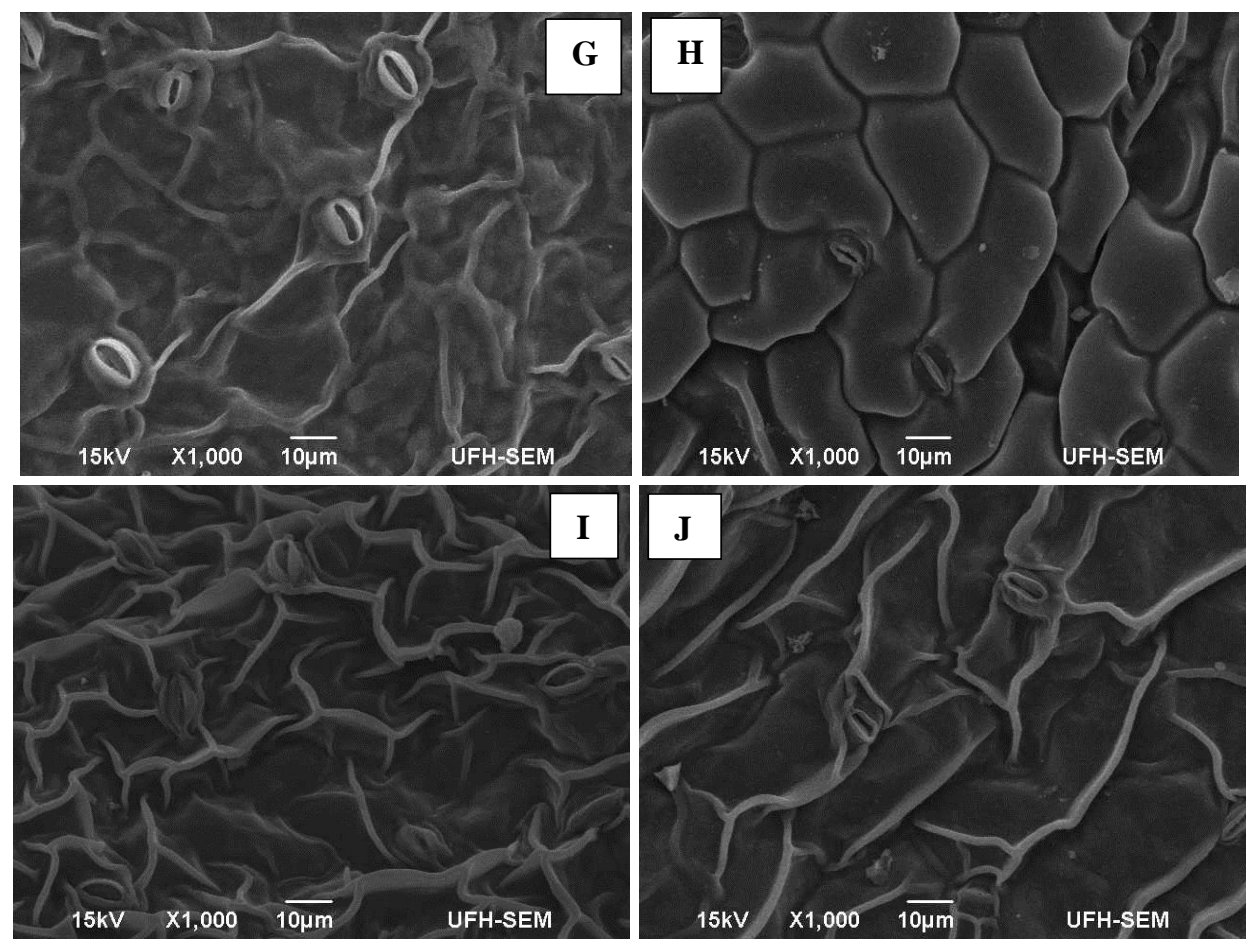

Figure 2. Plates $A, C, E, G \& I$ showing stomata number and distributions on abaxial layers; Plates $B, D, F, H \& J$ indicating stomata number and distributions on adaxial layers of $A$. caudatus cultivated on control soil, sandy clay loam, silty clay loam, clayey loam and loam respectively

Stomata density: This is defined as number of stomata per unit area. From SEM micrographs, stomata densities were higher on abaxial layers. In all soil types, the highest density (abaxial: $521.7 \pm 0.5$ stomata $/ \mathrm{mm}^{2}$; adaxial: $248.4 \pm 0.3$ stomata $/ \mathrm{mm}^{2}$ ) was observed in the clayey loam, followed by loam (abaxial: $397.5 \pm 0.7$ stomata $/ \mathrm{mm}^{2}$; adaxial: $198.8 \pm 0.5$ stomata $/ \mathrm{mm}^{2}$ ), sandy clay loam (abaxial: $372.7 \pm 0.5$ stomata $/ \mathrm{mm}^{2}$; adaxial: $99.4 .4 \pm 0.3$ stomata $/ \mathrm{mm}^{2}$ ), control soil (abaxial: $223.6 \pm 0.5$ stomata $/ \mathrm{mm}^{2}$; adaxial: $\quad 99.4 \pm 0.3$ stomata $/ \mathrm{mm}^{2}$ ) and silty clay loam (abaxial: $198.8 \pm 0.5 \mathrm{stomata} / \mathrm{mm}^{2}$; adaxial: $99.4 .4 \pm 0.3 \mathrm{stomata} / \mathrm{mm}^{2}$ ) with the least stomatal density (Table 2). The same stomata densities were evaluated for the adaxial layers of control $\left(\mathrm{SF}_{1}\right)$, sandy clay loam $\left(\mathrm{SF}_{2}\right)$ and silty clay loam $\left(\mathrm{SF}_{3}\right)$ soils. This was due to the fact that the same numbers of stomata were observed in their respective SEM micrographs.

Table 2. Effect of soil types on stomata characteristics

\begin{tabular}{c|c|c|c|c|c}
\hline Leaf indices & \multicolumn{5}{|c}{ Adaxial surface } \\
\hline Soil types & SF1 & SF2 & SF3 & SF4 & SF5 \\
Stomatal density $\left(\mathrm{mm}^{-2}\right)$ & $99.38 \pm 0.47^{\mathrm{b}}$ & $99.38 \pm 0.47^{\mathrm{b}}$ & $99.38 \pm 0.47^{\mathrm{b}}$ & $248.44 \pm 0.47^{\mathrm{a}}$ & $198.75 \pm 0.94^{\mathrm{ab}}$ \\
Distance between stomata $\left(\mathrm{mm}^{2}\right)$ & $128.07 \pm 6.92^{\mathrm{a}}$ & $153.53 \pm 43.01^{\mathrm{a}}$ & $75.53 \pm 13.3^{\mathrm{b}}$ & $41.13 \pm 5.73^{\mathrm{b}}$ & $52.6 \pm 9.22^{\mathrm{b}}$ \\
\hline & \multicolumn{5}{|c}{ Abaxial surface } \\
\hline Soil types & $\mathrm{SF} 1$ & $\mathrm{SF}$ & $\mathrm{SF}$ & $\mathrm{SF} 4$ & SF5 \\
Stomatal density $\left(\mathrm{mm}^{-2}\right)$ & $223.60 \pm 0.82^{\mathrm{a}}$ & $372.66 \pm 0.82^{\mathrm{b}}$ & $198.75 \pm 2.67^{\mathrm{c}}$ & $521.73 \pm 0.82^{\mathrm{a}}$ & $397.51 \pm 1.25^{\mathrm{ab}}$ \\
Distance between stomata $\left(\mathrm{mm}^{2}\right)$ & $51.93 \pm 6.82^{\mathrm{b}}$ & $53.67 \pm 5.73^{\mathrm{b}}$ & $60.43 \pm 7.01^{\mathrm{b}}$ & $34.43 \pm 4.91^{\mathrm{c}}$ & $50.03 \pm 4.43^{\mathrm{b}}$ \\
\hline
\end{tabular}

*Letters $\mathrm{a}, \mathrm{ab}, \mathrm{b}$ and $\mathrm{c}$ are different values of mean separations obtained from MINITAB 17 


\section{Trichomes}

Different kinds of trichomes namely; capitate, multicellular glandular, acicular and non-glandular dish-shaped peltate trichomes were seen on both layers of the epidermis of the plant samples examined. In some soils, the dish-shaped peltate trichomes had attached lids while in other cases, lids were absent. Both acicular and capitate trichomes were abundant on the upper surface than the lower surface (Fig. 3).

\section{Distance between stomata}

The distance between stomata and stomata density followed a characteristic trend. As stomata density increases, the distance decreases. Stomata were farthest away from one another on sandy clay loam (adaxial: $153.5 \pm 14.3 \mu \mathrm{m}$ ) and closest on clayey loam (abaxial: $34.4 \pm 1.6 \mu \mathrm{m}$ ) with each soil type following the trend earlier mentioned (Table 2).
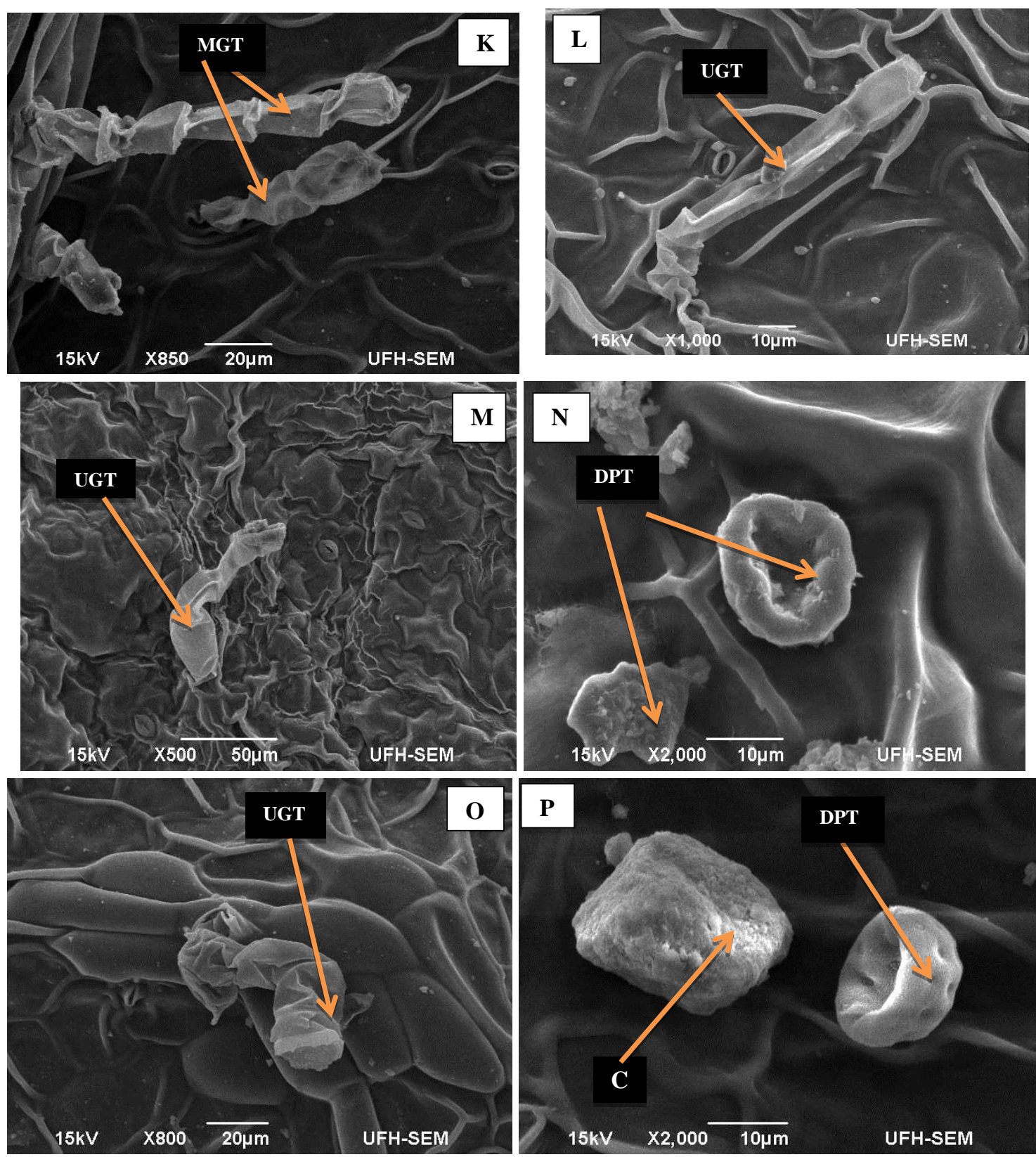

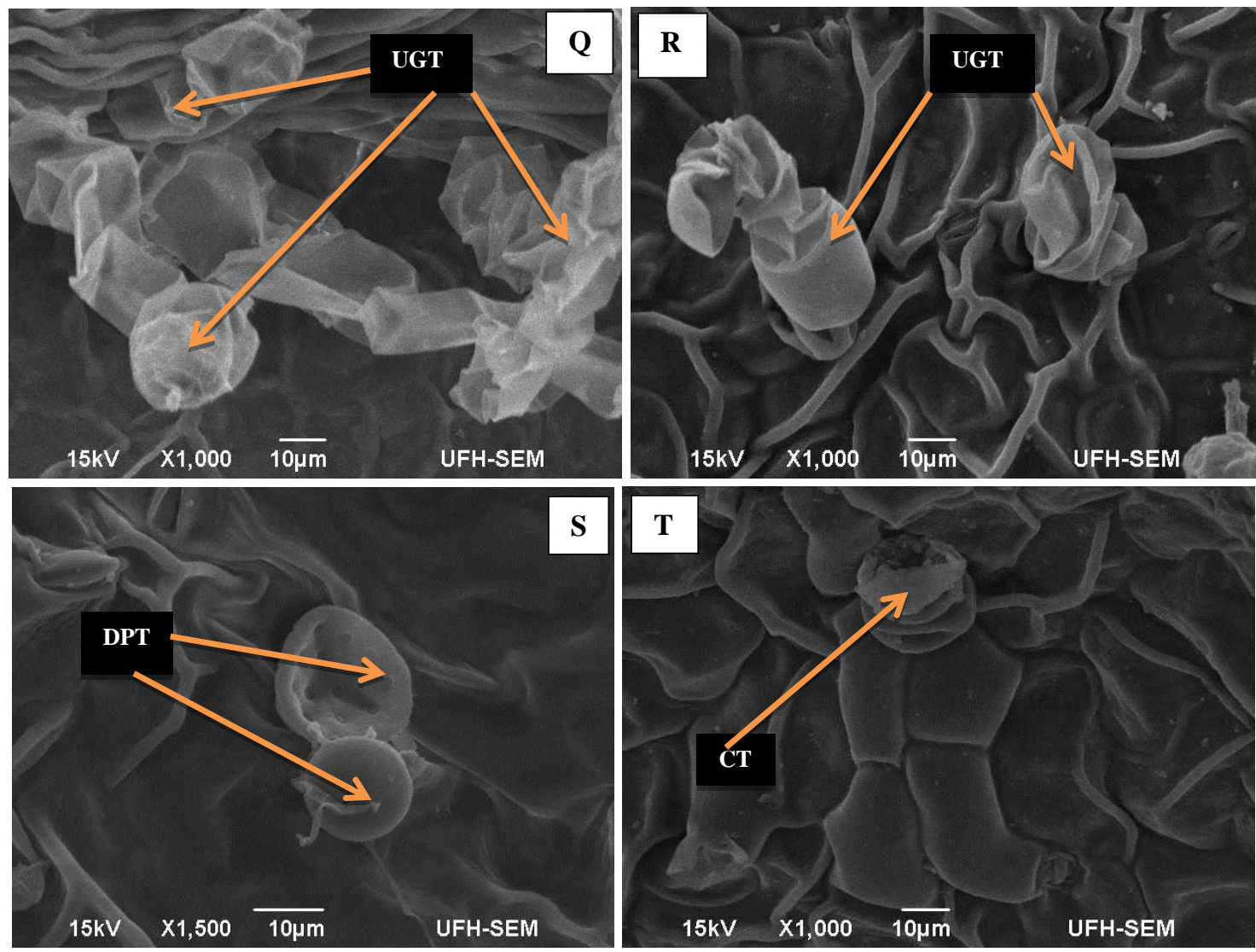

Figure 3. Plates $K, L, M, N \& O$ showing different trichomes on abaxial layers; Plates $P, Q, R$, $S \& T$ indicating trichomes on adaxial layers of A. caudatus cultivated on control soil, sandy clay loam, silty clay loam, clayey loam and loam respectively. $M G T=$ multicellular glandular trichome; UGT = unicellular glandular trichome; DPT = dish-like peltate trichome;

$C T=$ capitate trichome; $C=$ crystal

\section{Epidermal cells}

The epidermal cell walls in all soil types were irregular in shape, with curved anticlinal walls but later assumed polygonal shape when swollen. The anticlinal walls became straight when turgid, conferring the polygonal shape on the epidermal cell (Fig. $4 W \& X$ ). The epidermal cells on the adaxial layer developed into distinct polygonal sacs that may serve as storage facilities for essential oil, water or phytochemicals. Also, crystal deposits were found on the epidermal layers which may indicate the presence of chemicals that offer mechanical support to the leaf (Fig. 4).

\section{Energy dispersive $X$-ray (EDX) spectroscopy}

The EDX analysis of the epidermal layers revealed percentage atomic composition of various elements as presented in Table 3. Presumably, high presence of gold was due to the gold coating. Beryllium was found in high quantity only in the control soil whereas it is absent in the plant grown on formulated soils. Elements such as carbon, nitrogen, oxygen, sodium, magnesium, silicon, phosphorus, sulphur, potassium and calcium were found in quantifiable amount from all harvested plants. Plants harvested from the control soil $\left(\mathrm{SF}_{1}\right)$ and sandy clay loam $\left(\mathrm{SF}_{2}\right)$ lack aluminium which is present in low 
quantity in the harvest from other soil types. Chlorine, iron, manganese and zinc were found in extremely low amount although still lacking in some harvested samples of $A$. caudatus (Table 3; Fig. 5).
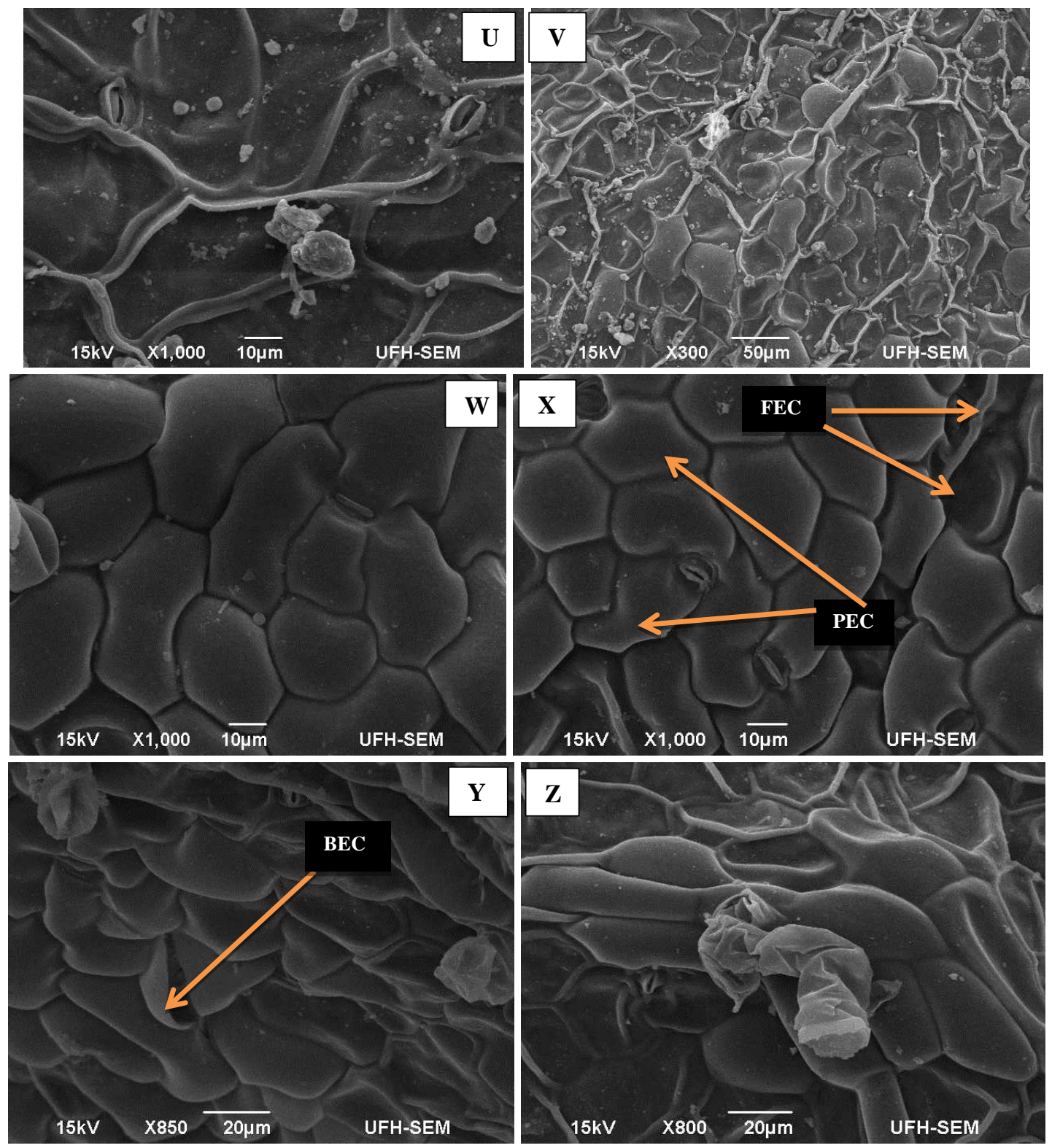

Figure 4. Plates $U$ \& $V$ showing flaccid epidermal cells on abaxial and adaxial layers of harvest from the control soil respectively; Plate $W \& X$ indicating turgid epidermal cells on adaxial layers of A. caudatus cultivated on sandy clay loam and clayey loam respectively.;

Plate $Y$ showing burst epidermal sac on adaxial layer of harvest from loam soil; Plate Z indicating swollen epidermal cell on adaxial layer of harvest from silty clayey loam

\section{Discussion}

The taxonomic significance of micro-characters in delimiting Amaranthus species has been explored deeply; however, there is dearth of information on modifications induced by soil types to distribution, types and frequency of these characters. Recent investigations by Costea et al. (2006) and Ogundipe and Kadiri (2012) revealed some 
diagnostic micro-molecular characters in Amaranthaceae. Among these ultra-structures of interest are stomata and trichomes. This study established how soil type modulates stomata densities, trichome types, sizes, frequency and protrusion of epidermal cells due to storage of water, accumulation of essential oils and phytochemicals.

The amphistomatic nature of the epidermal layers of $A$. caudatus remained intact in all soil types although with varying stomatal densities, distribution and, development of solitary, dish-like stellate trichomes that play major roles in secretion and storage of bioactive compounds (Ogundipe and Kadiri, 2012; Wagner et al., 2004). From the figures presented in this study, stomata densities increased in the order $\mathrm{SF}_{3}<\mathrm{SF}_{1}<\mathrm{SF}_{2}<\mathrm{SF}_{5}<\mathrm{SF}_{4}$ (abaxial) and $\mathrm{SF}_{1}=\mathrm{SF}_{2}=\mathrm{SF}_{3}<\mathrm{SF}_{5}<\mathrm{SF}_{4}$ (adaxial). This implies that $\mathrm{SF}_{4}$ (clayey loam) with the highest clay content provided the most suitable environment for stomata development and proliferation than other soil types. This may not be unconnected with increased clay content (compared to other soil formulations) that must have conferred high water retention capacity on the soil since water retention capacity depends on soil physical characteristics (Rawls et al., 1991; Rabot et al., 2018). Thus, the plant may have been compelled to evolve an adaptive mechanism for a more efficient evapotranspiration, leading to increased number of stomata on both epidermal layers. Also, all harvested samples from different soils followed the common trend of higher stomata index on the abaxial layers compared to the adaxial (Babber and Dhingra, 1985; De Micco et al., 2011; Jimoh and Olowokudejo, 2017).

The non-glandular dish-shaped peltate trichomes are being reported for Amaranthus caudatus for the first time. This kind of trichome was not observed in the plant harvested from the control and clayey loam. In addition, no lid was found in the abaxial layer of plant harvested from silty clay loam. Also, membranous lid was seen attached to the trichomes on the adaxial surfaces of harvest from loam and sandy clay loam. This observation is a key contribution to the taxonomy of Amaranthus caudatus in particular, and Amaranthaceae at large.

Table 3. Percentage compositions of the elements in A. caudatus leaf epidermis by EDX spectroscopy

\begin{tabular}{c|c|c|c|c|c}
\hline Elements & $\mathbf{S F}_{\mathbf{1}}$ & $\mathbf{S F}_{\mathbf{2}}$ & $\mathbf{S F}_{\mathbf{3}}$ & $\mathbf{S F}_{\mathbf{4}}$ & $\mathbf{S F}_{\mathbf{5}}$ \\
\hline Beryllium & $8.83 \pm 0.33$ & 0 & 0 & 0 & 0 \\
Carbon & $31.20 \pm 0.60$ & $29.15 \pm 0.67$ & $26.60 \pm 0.73$ & $27.88 \pm 1.16$ & $30.00 \pm 0.69$ \\
Nitrogen & $5.03 \pm 1.24$ & $5.38 \pm 1.67$ & $2.98 \pm 1.60$ & $6.86 \pm 2.10$ & $4.48 \pm 1.58$ \\
Oxygen & $20.77 \pm 0.42$ & $23.91 \pm 0.55$ & $19.95 \pm 0.54$ & $26.83 \pm 0.74$ & $24.43 \pm 0.54$ \\
Sodium & $0.73 \pm 0.07$ & $2.03 \pm 0.17$ & $1.26 \pm 0.10$ & $3.00 \pm 0.11$ & $0.83 \pm 0.09$ \\
Magnesium & $1.10 \pm 0.08$ & $1.26 \pm 0.11$ & $1.74 \pm 0.12$ & $0.62 \pm 0.07$ & $1.24 \pm 0.11$ \\
Aluminium & 0 & 0 & $0.15 \pm 0.06$ & $0.04 \pm 0.04$ & $0.05 \pm 0.05$ \\
Silicon & $0.84 \pm 0.08$ & $0.03 \pm 0.03$ & $0.07 \pm 0.06$ & $0.08 \pm 0.07$ & $0.22 \pm 0.05$ \\
Phosphorus & $0.43 \pm 0.11$ & $0.53 \pm 0.13$ & $0.75 \pm 0.15$ & $0.81 \pm 0.18$ & $0.41 \pm 0.13$ \\
Sulphur & $0.53 \pm 0.11$ & $0.47 \pm 0.14$ & $1.28 \pm 0.18$ & $1.18 \pm 0.19$ & $0.29 \pm 0.15$ \\
Chlorine & $0.32 \pm 0.05$ & $0.09 \pm 0.07$ & $0.12 \pm 0.08$ & 0 & 0 \\
Potassium & $3.53 \pm 016$ & $4.68 \pm 0.22$ & $3.34 \pm 0.22$ & $3.96 \pm 0.29$ & $1.54 \pm 0.18$ \\
Calcium & $0.14 \pm 0.07$ & $0.72 \pm 0.10$ & $0.51 \pm 0.11$ & $1.68 \pm 0.15$ & $0.27 \pm 0.09$ \\
Iron & 0 & $0.20 \pm 0.20$ & 0 & 0 & 0 \\
*Gold & $26.56 \pm 4.09$ & $31.28 \pm 5.19$ & $40.92 \pm 5.70$ & $26.42 \pm 6.57$ & $35.24 \pm 5.18$ \\
Manganese & 0 & $0.26 \pm 0.18$ & $0.22 \pm 0.20$ & 0 & 0 \\
Zinc & 0 & 0 & $0.11 \pm 0.11$ & $0.65 \pm 0.65$ & 0 \\
\hline
\end{tabular}

*High percentage of gold was presumably due to the gold plating 


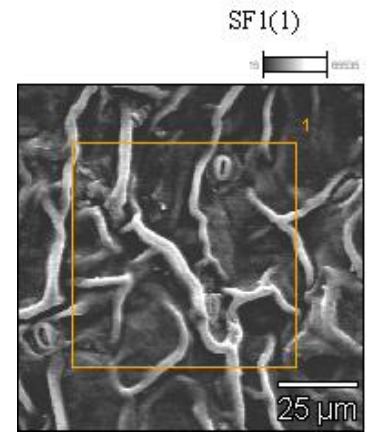

SF 2(1)

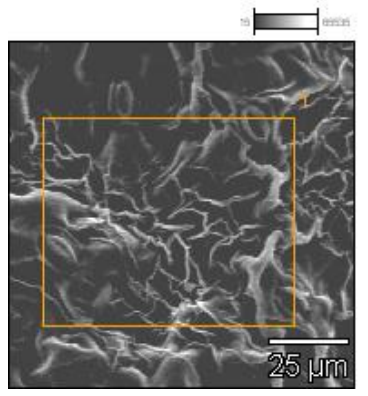

SF3(1)

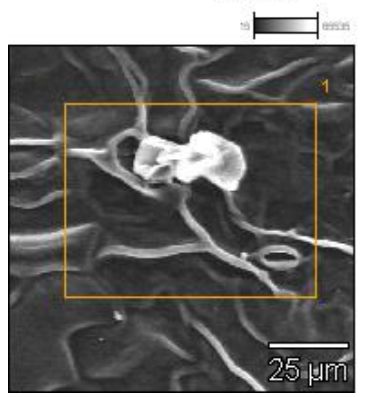

SF4(1)

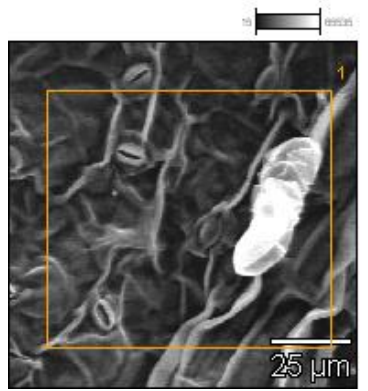

SF5(1)

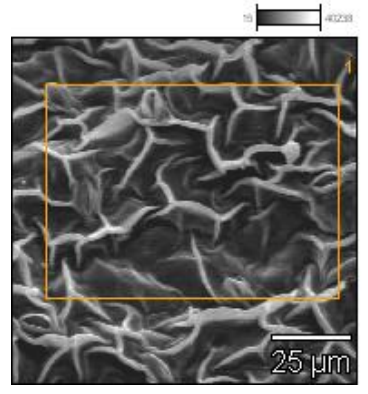

Full scale counts: $1273 \quad$ SF1(1)_pt1

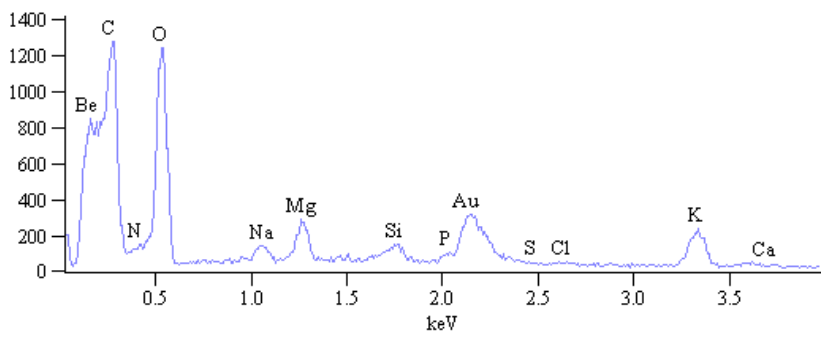

Full scale counts: 1148

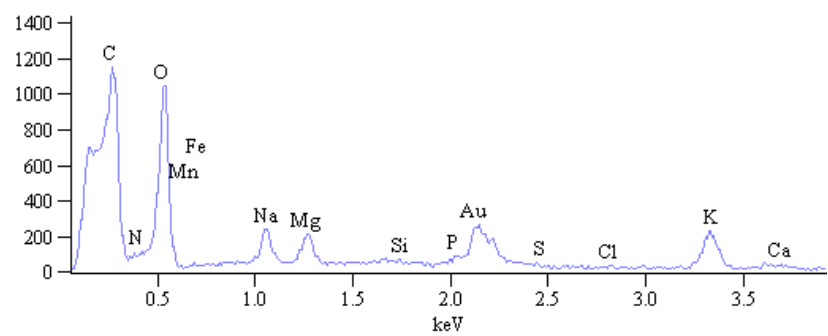

Full scale counts: $803 \quad$ SF3(1)_pt1

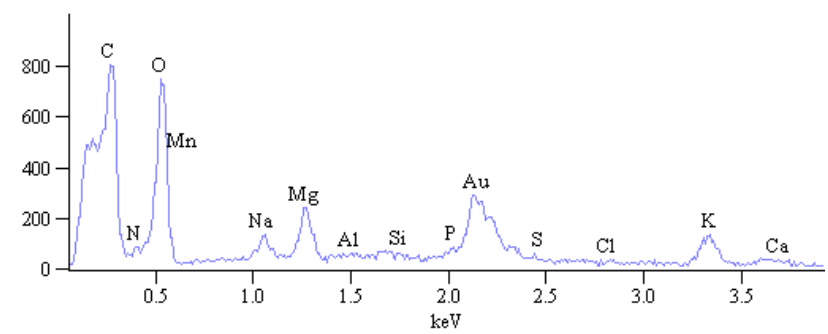

Full scale counts: $986 \quad$ SF4(1)_pt1

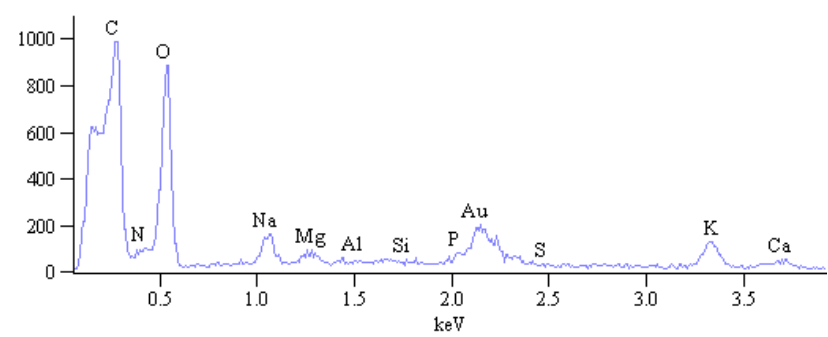

Full scale counts: $1150 \quad$ SF5(1)_pt1

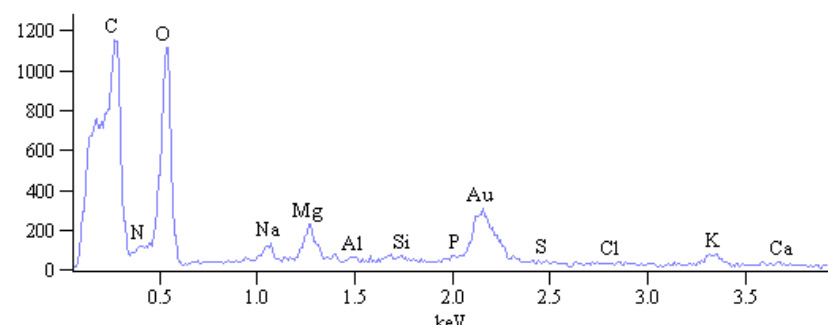

Figure 5. Percentage compositions of elements in A. caudatus leaf epidermis by EDX spectroscopy. SF1 = control soil; $S F 2$ = sandy clay loam; SF3 = silty clay loam; SF4 = clayey loam; SF5 = loam 
The analysis of percentage compositions of the elements in A. caudatus by EDX spectroscopy of the leaf epidermis revealed variations in elemental composition of the plant with regard to nutrient derived from the respective soil types used for cultivation. For example, harvests from clayey loam soil (with relative equal compositions of sand, silt and clay) had the highest composition of the following elements; nitrogen, oxygen, sodium, phosphorus, calcium and zinc whereas other elements were present in different proportions on epidermal surfaces of harvests from other soils. This finding might be a precursor to the highest biological activities recorded in harvests from clayey loam as reported in Jimoh et al., (2019b). This further corroborates earlier reports that nutrient uptake from the soil affects percentage composition of elements in plants (Ogundola et al., 2017; Ahmed et al., 2013).

\section{Conclusion}

Findings from this research revealed that formulated soil types modified the foliar epidermal characteristics in Amaranthus caudatus. Also, variabilities in stomatal densities and percentage elemental composition of the harvests further indicated that the relative proportion of primary soil particles (sand, silt and clay) in the formulated soils affects both nutrient uptake and the capacity for evapotranspiration via the stomata. The presence of special trichome; the dish-like non-glandular peltate trichome and other types may not be unconnected with secretion of essential phytochemicals responsible for high therapeutic effect of the plant. Undoubtedly, these soil types-induced modifications could be useful in achieving a robust taxonomic delimitation in Amaranthus caudatus as results obtained explained further, the impact of environment on foliar development.

Acknowledgements. Authors wish to acknowledge Dr Elizabeth Famewo Aladejana of MPED Research Centre and the Govan Mbeki Research and Development Centre respectively for their technical and financial support.

Conflict of interests. We declare no conflict on this manuscript.

\section{REFERENCES}

[1] Ahmed, A. H. H., Darwish, E., Alobaidy, M. G. (2013): Effect of putrescine and humic acid on growth, yield and chemical composition of cotton plants grown under saline soil conditions. - American-Eurasian Journal of Agricultural and Environmental Sciences 13(4): 479-497.

[2] Babber, S., Dhingra, H. R. (1985): Foliar epidermal studies in Amaranthaceae. - Current Science Association 54(14): 707-709.

[3] Casson, S., Gray, J. E. (2008): Influence of environmental factors on stomatal development. - New Phytologist 178(1): 9-23.

[4] Christenhusz, M. M. J., Byng, J. W. (2016): The number of known plants species in the world and its annual increase. - Phytotaxa 261(3): 201-217.

[5] Costea, M., Brenner, D. M., Tardif, F. J., Tan, Y. F., Sun, M. (2006): Delimitation of Amaranthus cruentus L. and Amaranthus caudatus L. using micromorphology and AFLP analysis: an application in germplasm identification. - Genetic Resources and Crop Evolution 53: 1625-1633. 
[6] De Micco, V., Arena, C., Vitale, L., Aronne, G. (2011): Anatomy and photochemical behaviour of Mediterranean Cistus incanus winter leaves under natural outdoor and warmer indoor conditions. - Botany 89: 677-688.

[7] Fank-De-Carvalho, S. M., Gomes, M. R. de A., Silva, P. Í. T., Báo, S. N. (2010): Leaf surfaces of Gomphrena spp. (Amaranthaceae) from Cerrado biome. - Biocell 34(1): 2335 .

[8] Jimoh, M. O., Olowokudejo, J. D. (2017): Leaf epidermal morphology and petiole anatomy of the genus Anthocleista Afzel. ex R. Br . (Gentianaceae). - Journal of Tropical Agriculture 55(2): 121-133.

[9] Jimoh, M. O., Afolayan, A. J., Lewu, F. B. (2018): Suitability of Amaranthus species for alleviating human dietary deficiencies. - South African Journal of Botany 115: 65-73. https://doi.org/10.1016/j.sajb.2018.01.004.

[10] Jimoh, M. O., Afolayan, A. J., Lewu, F. B. (2019a): Germination response of Amaranthus caudatus L. to soil types and environmental conditions. - Thaiszia Journal of Botany 29(1): 85-100.

[11] Jimoh, M. O., Afolayan, A. J., Lewu, F. B. (2019b): Antioxidant and phytochemical activities of Amaranthus caudatus L. harvested from different soils at various growth stages. - Scientific Reports 9: 12965

[12] Juan, R., Pastor, J., Alaiz, M., Vioque, J. (2007): Electrophoretic characterization of Amaranthus L. seed proteins and its systematic implications. - Botanical Journal of the Linnean Society 155(1): 57-63.

[13] Kadereit, G., Borsch, T., Weising, K., Freitag, H. (2003): Phylogeny of Amaranthaceae and Chenopodiaceae and the evolution of $\mathrm{C} 4$ photosynthesis. - International Journal of Plant Sciences 164(6): 959-986.

[14] Maherali, H., Reid, C. D., Polley, H. W., Johnson, H. B., Jackson, R. B. (2002): Stomatal acclimation over a sub ambient to elevated $\mathrm{CO} 2$ gradient in a $\mathrm{C} 3 / \mathrm{C} 4$ grassland. - Plant, Cell and Environment 25(4): 557-566. http://doi.wiley.com/10.1046/j.13653040.2002.00832.x 23 December 2018.

[15] Munien, P., Naidoo, Y., Naidoo, G. (2015): Micromorphology, histochemistry and ultrastructure of the foliar trichomes of Withania somnifera (L.) Dunal (Solanaceae). Planta 242(5): 1107-1122.

[16] Ogundipe, O. T., Kadiri, A. B. (2012): Comparative foliar epidermal morphology of the West African species of Amaranthaceae Juss. - Feddes Repertorium 123(2): 97-116.

[17] Ogundola, A. F., Bvenura, C., Afolayan, A. J. (2017): Morphological assessment of the roots, stems and leaves of Solanum nigrum L. Cultivated on different soil types. Applied Ecology and Environmental Research 15(1): 787-798.

[18] Olesen, T., Moldrup, P., Gamst, J. (1999): Solute Diffusion and Adsorption in Six Soils along a Soil Texture Gradient. - Soil Science Society of America Journal 63(3): 519-524. https://www.soils.org/publications/sssaj/abstracts/63/3/SS0630030519 4 April 2019.

[19] Pillitteri, L. J., Torii, K. U. (2012): Mechanisms of Stomatal Development. - The Annual Review of Plant Biology 63: 591-614. www.annualreviews.org (accessed on 4 April 2019).

[20] Rabot, E., Wiesmeier, M., Schlüter, S., Vogel, H. J. (2018): Soil structure as an indicator of soil functions: a review. - Geoderma 314: 122-137. https://doi.org/10.1016/j.geoderma.2017.11.009.

[21] Rastogi, A., Shukla, S. (2013): Amaranth: a new millennium crop of nutraceutical values. - Critical Reviews in Food Science and Nutrition 53(2): 109-125.

[22] Rawls, W. J., Gish, T. J., Brakensiek, D. L. (1991): Estimating Soil Water Retention from Soil Physical Properties and Characteristics. - In: Stewart, B. A. (ed.) Advances in Soil Science. Springer-Verlag, New York, pp. 213-234. http://link.springer.com/10.1007/9781-4612-3144-8_5 (accessed on 4 April 2019).

[23] Shah, S. N., Ahmad, M., Zafar, M., Razzaq, A., Malik, K., Rashid, N., Ullah, F., Iqbal, M., Zaman, W. (2018): Foliar epidermal micromorphology and its taxonomic 
implications in some selected species of Athyriaceae. - Microscopy Research and Technique. https://doi.org/10.1002/jemt.23055.

[24] Sharaibi, O. J., Afolayan, A. J. (2017): Micromorphological characterization of the leaf and rhizome of Agapanthus praecox subsp. praecox Willd. (Amaryllidaceae). - Journal of Botany. https://doi.org/10.1155/2017/3075638.

[25] Stuessy, T. F. (2009): Plant Taxonomy: The Systematic Evaluation of Comparative Data. - Columbia University Press, New York.

[26] The Angiosperm Phylogeny Group (2009): An update of the Angiosperm phylogeny group classification for the orders and families of flowering plants: APG III. - Botanical Journal of the Linnean Society 161(2): 105-121.

[27] United States Department of Agriculture \& Natural Resources Conservation Service (1983): National Soil Survey Handbook (NSSH). NRCS Soils. https://www.nrcs.usda.gov/wps/portal/nrcs/detail/soils/ref/?cid=nrcs142p2_054242 (accessed on 5 April 2019).

[28] Viger, M., Hancock, R. D., Miglietta, F., Taylor, G. (2015): More plant growth but less plant defence? First global gene expression data for plants grown in soil amended with biochar. - GCB Bioenergy 7(4): 658-672.

[29] Wagner, G. J., Wang, E., Shepherd, R. W. (2004): New approaches for studying and exploiting an old protuberance, the plant trichome. - Annals of Botany 93(1): 3-11. 